\title{
YIELD AND NITROGEN USE EFFICIENCY OF LOCALLY IMPROVED RICE VARIETIES IN RICE BASED TIDAL FLOODED ECOSYSTEM OF BANGLADESH
}

\author{
M. A. A. Mamun ${ }^{*}$, M. M. Haque ${ }^{1}$, Q. A. Khaliq ${ }^{1}$, M. A. Karim ${ }^{1}$, \\ A. J. M. S. Karim ${ }^{1}$, A. J. Mridha ${ }^{2}$ and M. A. Saleque ${ }^{2}$ \\ ${ }^{1}$ Bangabandhu Sheikh Mujibur Rahman Agricultural University, Gazipur 1706, Bangladesh \\ ${ }^{2}$ Bangladesh Rice Research Institute, Gazipur 1701, Bangladesh \\ *Corresponding address: aamamunbrri@yahoo.com
}

Key words: Grain yield, nitrogen uptake, nitrogen harvest index, rice cultivars, tidal ecosystem

\begin{abstract}
An on farm field experiment was conducted to evaluate locally improved aman rice varieties in terms of nitrogen use efficiency and grain yield in southern region of Bangladesh. The treatments were: i. deep placement of urea (UDP) before panicle initiation stage and ii. farmers' practice (FP/control). The locally popular rice varieties were used as planting materials. Higher panicles $\mathrm{m}^{-2}$ and grains panicle ${ }^{-1}$ was obtained from UDP application compared to FP. Nitrogen fertilization increases grain and straw nitrogen content significantly. Application of urea before panicle initiation stage gave considerable higher grain yield in all cultivated varieties. Cultivated aman varieties produced 2.0 to $2.5 \mathrm{t} \mathrm{ha}^{-1}$ grain without application of $\mathrm{N}$ fertilizer. But, cultivated local variety Razashail, Kutiagoni, Sadachikon, Sadapajam, Lalmota and Sadamota gave 3.0 to $3.5 \mathrm{t}$ ha $^{-1}$ grain in tidal prone areas with UDP. Hence, application of urea gave yield advantage by 0.5 to $1.0 \mathrm{t} \mathrm{ha}^{-1}$. The highest internal, agronomic, recovery and physiological efficiency; nitrogen harvest and grain yield efficiency index was obtained from Kutiagoni, Lalpayka, Sadachikon, Sadapajam, Moulata and Lalmota. Based on the yield and nitrogen fertilizer use efficiency, it could be concluded that UDP before panicle initiation stage is an effective option of urea application for rice cultivation in tidal prone areas.
\end{abstract}

\section{Introduction}

Tidal flooded ecosystem is one of the major unfavorable agro-ecological situations (Hossain et al., 2002) for crop cultivation. Around 1.0 million hectare of land is tidal prone in southern region (Elahi et al., 2001) of Bangladesh. The hydrology of this area influences the agricultural ecosystem, cropping system and farmers socioeconomic condition. Aman rice is the major crop in tidal prone areas in Bangladesh. Farmers do not apply fertilizer especially nitrogen $(\mathrm{N})$ in aman season in tidal areas because there is a high risk of surface losses to floodwater. As a result, the yield of cultivated local varieties is low. On the other hand, application of $\mathrm{N}$ increases grain and straw yield as well as $\mathrm{N}$ use efficiency (Hassan et al., 2009). Nitrogen is considered as the most important nutrients in improving rice yields under most agro-ecosystem (Fageria and Santos, 2014). However, nitrogen can improve leaf $N$ concentration, photosynthetic rate, delay in leaf senescence, and increase in the amount of dry matter for grain filling, thus improve the productivity of rice (Mnzava, 2002). Moreover, $\mathrm{N}$ is responsible for improving panicle size (increase number of filled grains panicle $e^{-1}$ ) and grain weight and responsible for reducing spikelet sterility (Fageria, 2009). Hence, the efficient use of $\mathrm{N}$ can increase grain yield through improving panicle number, thousand grain weights and reducing sterility percent (Fageria, 2007). Thus, a 
Mamun et al.

suitable $\mathrm{N}$ management technique is needed which will increase the grain fertility, reduce spikelets sterility and improve rice grain yield in tidal flood prone areas.

Top dressing of prilled (PU) and deep placement (UDP) of urea super granule (USG) are the two methods of $\mathrm{N}$ fertilization in Bangladesh. In tidal flooded areas, surface application of $\mathrm{N}$ fertilizer like $\mathrm{PU}$ is not possible due to high risk of surface loss (Rochette et al., 2013). But, deep placement of urea reduces $\mathrm{N}$ concentration in the floodwater; thus, it reduces $\mathrm{N}$ loss and increases uptake by the rice plant. Deep placement of urea increases $\mathrm{N}$ use efficiency up to 50 to $70 \%$, increases grain yield by 15 to 20\%, and reduces fertilizer $\mathrm{N}$ use by 30 to 40\% (Alam et al., 2013; IFDC, 2013). Therefore, deep placement of urea may a good alternative for efficient $N$ use and higher yield of rice in tidal flooded areas. This would restrict the vigorous vegetative growth and preventing lodging of the crop. The objective of this study was to evaluate locally improved aman rice varieties in terms of yield and nitrogen use efficiency in tidal ecosystem of Bangladesh.

\section{Materials and Methods}

\section{Locations}

A farmer participatory field experiment was conducted at Gournadi, Bakergonj of Barisal and Batagi under Borguna district. The area covers southern part of the country belongs to Agro Ecological Zone-13 named Ganges Tidal Floodplain. The experiment was conducted during July to December, 2013. Only urea super granule (USG of $1.8 \mathrm{~g}$ size) applied in treatment plots. No fertilizer was applied in farmers practice (FP) plot. Locally popular Aman varieties were used as planting materials. The urea super granule (USG) was applied at first week of September to October (before PI). As the site of experiment was flooded daily, USG was applied after recession of tidal water. The experiment is laid out in split plot design with three replications (Table 1).

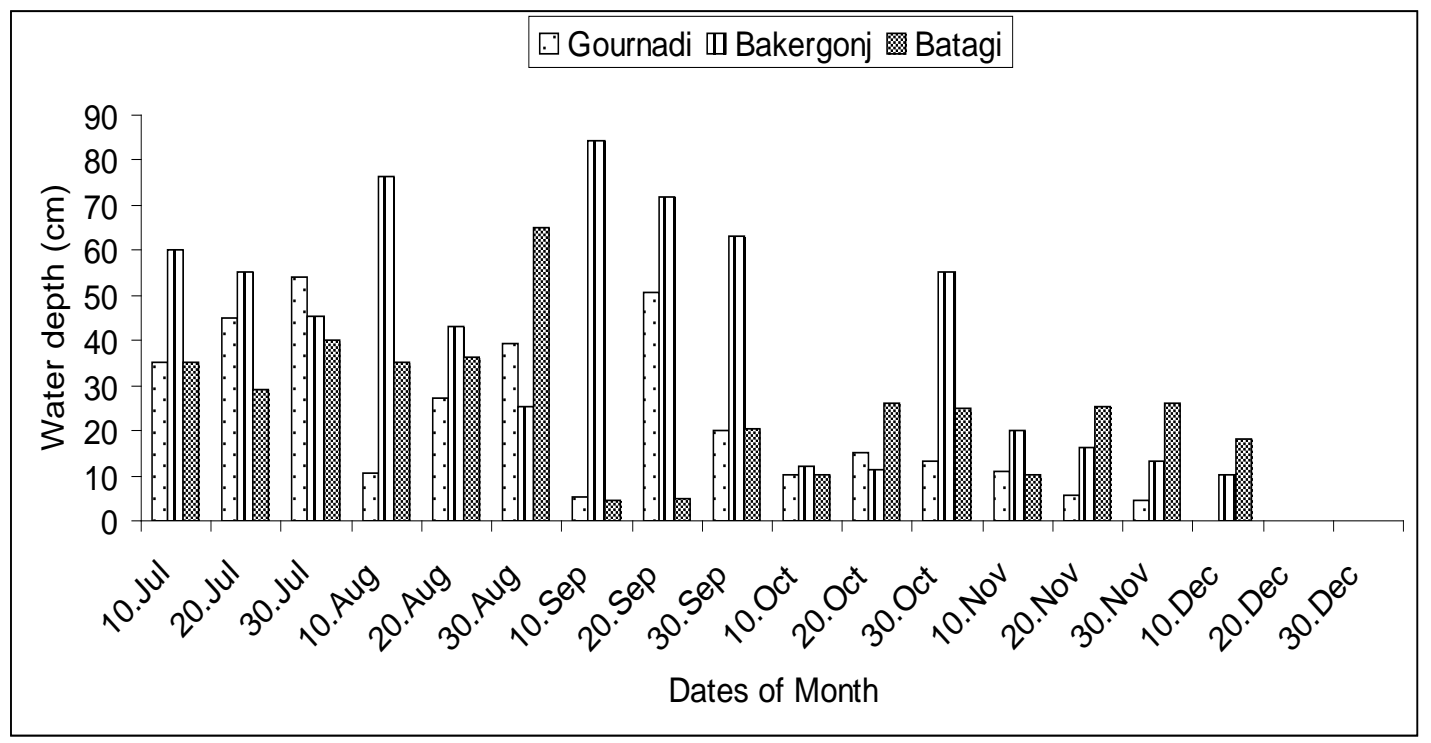

Fig. 1. Depth of tidal water enter into the crop fields

Table 1. The detail treatments for farmers' participatory field trials 
Yield and Nitrogen Use Efficiency of Locally Improved Rice Varieties in Rice Based

\begin{tabular}{|c|c|c|c|}
\hline Locations & Factor A (rice & variety) & Factor B (nitrogen) \\
\hline $\begin{array}{l}\text { Gournadi, } \\
\text { Barisal }\end{array}$ & $\begin{array}{l}\text { i. Razashail, } \\
\text { Kutiagoni, } \\
\text { iii. Lalpayka, } \\
\text { Sadachikon, } \\
\text { v. Mutha, } \\
\text { Lalchikon, } \\
\text { vii. Lothor, } \\
\text { Sadapajam }\end{array}$ & $\begin{array}{r}\text { ii. } \\
\text { iv. } \\
\text { vi. } \\
\text { viii. }\end{array}$ & $\begin{array}{l}\text { i. Deep placement of urea (UDP) } \\
\text { super granule before panicle } \\
\text { initiation (PI) stage, and } \\
\text { ii. No fertilizer (control) }\end{array}$ \\
\hline $\begin{array}{l}\text { Bakerganj, } \\
\text { Barisal }\end{array}$ & $\begin{array}{l}\text { i. } \quad \text { Sadamota } \\
\text { ii. Lalmota } \\
\text { iii. } \text { Moulata }\end{array}$ & & $\begin{array}{l}\text { i. UDP before PI stage, and } \\
\text { ii. No fertilizer (control) }\end{array}$ \\
\hline $\begin{array}{l}\text { Betagi, } \\
\text { Barguna }\end{array}$ & $\begin{array}{ll}\text { i. } & \text { Sadamota } \\
\text { ii. } & \text { Lalmota } \\
\text { iii. } & \text { Moulata }\end{array}$ & & $\begin{array}{l}\text { i. UDP before PI stage, and } \\
\text { ii. No fertilizer (control) }\end{array}$ \\
\hline
\end{tabular}

The panicle numbers were determined from 16 hill sample at harvesting. The grains were separated and counted following standard procedures (Yoshida et al., 1976). Rice plants from $5 \mathrm{~m}^{2}$ area of the middle of each plot were harvested at ground level and threshed. The grains were dried in sunlight and winnowed before weighing and the seed yield was adjusted to $14 \%$ moisture content. Grain and straw nitrogen was determined from the collected plant samples by micro Kjeldahl method (Yoshida et al., 1976). The efficiency of applied $\mathrm{N}$ and $\mathrm{N}$ taken up by the rice crop were assessed using the following five different indices (Dobermann and Fairhurst, 2000).

a. Agronomic efficiency $(\mathrm{AE})$ : $\mathrm{AE}$ is the $\mathrm{kg}$ grain yield increase $\mathrm{kg}^{-1} \mathrm{~N}$ applied. $\mathrm{AE}_{\mathrm{N}}$ $=\left(G_{+N}-G Y_{0 N}\right) / F N$; Where, $A E_{N}=A E$ of $N ; G Y_{+N}=$ Grain yield due to addition of $\mathrm{FN} ; \mathrm{GY}_{0 \mathrm{~N}}=$ Grain yield without addition of $\mathrm{N}$; $\mathrm{FN}=$ Amount of $\mathrm{N}$ applied (kg ha-1).

b. Recovery efficiency (RE): $\mathrm{RE}$ is the $\mathrm{kg} \mathrm{N}$ taken up by the crop $\mathrm{kg}^{-1} \mathrm{~N}$ applied. $\mathrm{RE}_{\mathrm{N}}=\left(\mathrm{UN}_{+\mathrm{N}}-\mathrm{UN}_{\mathrm{ON}}\right) / \mathrm{FN}$; Where, $\mathrm{RE}_{\mathrm{N}}=\mathrm{RE}$ of $\mathrm{N} ; \mathrm{UN}_{+\mathrm{N}}=$ Plant $\mathrm{N}$ uptake with addition of $\mathrm{FN} ; \mathrm{UN}_{0} \mathrm{~N}=$ Plant $\mathrm{N}$ uptake without addition of $\mathrm{N} ; \mathrm{FN}=$ Amount of $\mathrm{N}$ applied $\left(\mathrm{kg} \mathrm{ha}{ }^{-1}\right)$.

c. Physiological efficiency (PE): $\mathrm{PE}$ is the $\mathrm{kg}$ grain yield increase $\mathrm{kg}^{-1} \mathrm{~N}$ taken up. $P E_{N}=\left(G Y_{+} N-G Y_{0}{ }_{N}\right) /\left(U N_{+N}-U_{0} N_{0}\right)$; Where, $P E_{N}=$ Physiological efficiency of $\mathrm{N} ; \mathrm{GY}_{+\mathrm{N}}=$ Grain yield due to addition of $\mathrm{FN} ; \mathrm{GY}_{0 \mathrm{~N}}=$ Grain yield without addition of $\mathrm{N} ; \mathrm{UN}_{+} \mathrm{N}=$ Plant $\mathrm{N}$ uptake with addition of $\mathrm{FN} ; \mathrm{UN}_{\mathrm{ON}}=$ Plant $\mathrm{N}$ uptake without addition of $\mathrm{N}$.

d. Partial factor productivity (PFP): PFP is the $\mathrm{kg}$ grain yield $\mathrm{kg}^{-1} \mathrm{~N}$ applied. $\mathrm{PFP}_{\mathrm{N}}=$ $\mathrm{GY}_{+\mathrm{N}} / \mathrm{FN}$; Where, $\mathrm{PFP}_{\mathrm{N}}=\mathrm{PFP}$ of $\mathrm{N} ; \mathrm{GY}_{+\mathrm{N}}=$ Grain yield due to addition of $\mathrm{FN} ; \mathrm{FN}=$ Amount of $\mathrm{N}$ applied $\left(\mathrm{kg} \mathrm{ha}^{-1}\right)$.

e. Internal efficiency (IE): IE is the $\mathrm{kg}$ grain yield $\mathrm{kg}^{-1} \mathrm{~N}$ taken up. $\mathrm{IE}_{\mathrm{N}}=\mathrm{GY} / \mathrm{UN}$; Where, $\mathrm{IE}_{\mathrm{N}}=$ Internal efficiency of $\mathrm{N} ; \mathrm{GY}=$ Grain yield $\left(\mathrm{kg} \mathrm{ha}{ }^{-1}\right) ; \mathrm{UN}=$ Total $\mathrm{N}$ uptake (kg ha-1).

f. Nitrogen harvest index (NHI): Nitrogen harvest index is defined as the ratio between nitrogen $(\mathrm{N})$ uptake in grain and $\mathrm{N}$ uptake in grain plus straw or shoot.

Nitrogen harvest index $=$ Nitrogen uptake in grain / Nitrogen uptake in grain and shoot

g. Grain yield efficiency index (GYEI): Grain yield is the best measure of a genotype evaluation in a screening (Fageria and Santos, 2014).

$$
\mathrm{GYEI}=\left(\mathrm{GY}_{1} / \mathrm{AYG}_{1}\right) \text { ч }\left(\mathrm{GY}_{2} / \mathrm{AGY}_{2}\right)
$$

Where, $\mathrm{GY}_{1}=$ Grain yield at control, $\mathrm{AGY}_{1}=$ average grain yield of genotypes at control, $\mathrm{GY}_{2}=$ grain yield at $\mathrm{N}$ applied and $\mathrm{AGY}_{2}=$ average grain yield of 
Mamun et al.

genotypes at $\mathrm{N}$ applied. Genotypes having GYEI values $>1.0$ were classified as efficient, genotypes which were having GYEI between 0.5 to 1.0 were classified as moderately efficient and those with GYEI values $<0.5$ were classified as inefficient.

Data analysis

Record data were analyzed statistically using MSTAT-C (Russell, 2010) package and difference among the treatment means were adjust using Duncan's multiple range tests (Gomez and Gomez, 1984).

\section{Results and Discussion}

\section{Yield contributing attributes and grain yield}

Urea super granule (USG) applied plot produced higher number of panicles $\mathrm{m}^{-2}$. The highest number of panicles $\mathrm{m}^{-2}$ was obtained from Lothor, Lalmota and Moulata at Gournadi, Bakergonj and Batagi, respectively (Table 2, $3 \& 4$ 4). Sadapajam at Gournadi, Moulata at Bakergonj and Sadamota at Batagi produced the highest number

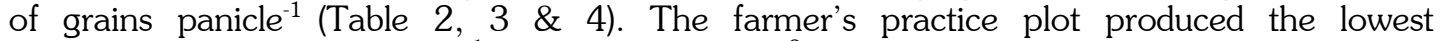
number of grains panicles ${ }^{-1}$ and panicles $\mathrm{m}^{-2}$ in all locations. At Gournadi, the maximum grain yield was recorded from Sadachikon followed by Sadapajam variety with USG application (Table 2). These two varieties gave more than $4.5 \mathrm{t} \mathrm{ha}^{-1}$ grain with $\mathrm{N}$ application. At Bakergonj, numerically maximum grain yield was recorded from Lalmota variety with USG application (Table 3). This variety produced 3.35 and 2.45 $\mathrm{t} \mathrm{ha}^{-1}$ with $\mathrm{N}$ and control, respectively. At Batagi, numerically maximum grain yield was recorded from Lalmota variety with $\mathrm{N}$-application (Table 4). The application of USG gave 0.5 to $1.0 \mathrm{t} \mathrm{ha}^{-1}$ yield advantages compared to farmer's practice in all locations. In this study, higher number of panicles $\mathrm{m}^{-2}$ and grains panicles ${ }^{-1}$ were obtained from the addition of $\mathrm{N}$ compared to control (Tables 2 to 4). More number of panicles might be due to the more availability of nitrogen that played a vital role in cell division. These results are in accordance to the findings of Rajput et al. (1988). It was demonstrated that the deep placement of urea $(\mathrm{N})$ before panicle ignition stage of rice exerted significant effects on grain yield. At Gournadi, Sadapajam produced grain yield by 4.66 and $3.27 \mathrm{t} \mathrm{ha}^{-1}$ with addition of $\mathrm{N}$ and control, respectively (Table 2).

Table 2. Effect of urea deep placement on yield components of aman rice, Gournadi, Barisal.

\begin{tabular}{|c|c|c|c|c|c|c|}
\hline \multirow{2}{*}{ Varieties } & \multicolumn{2}{|c|}{ Panicles $\mathrm{m}^{-2}$} & \multicolumn{2}{|c|}{ Grains panicle $e^{-1}$} & \multicolumn{2}{|c|}{ Grain yield $\left(\mathrm{t} \mathrm{ha} \mathrm{h}^{-1}\right)$} \\
\hline & $\mathrm{N}$-applied & Control & N-applied & Control & $\mathrm{N}$-applied & Contro \\
\hline Razashail & $159 \mathrm{a}$ & $142 \mathrm{~d}$ & $90 \mathrm{c}$ & $75 \mathrm{~b}$ & $3.59 \mathrm{~b}$ & 2.80 \\
\hline Kutiagoni & $172 \mathrm{ab}$ & $151 \mathrm{bcc}$ & $90 \mathrm{c}$ & $79 \mathrm{~b}$ & $3.85 \mathrm{~b}$ & 3.35 \\
\hline Lalpayka & $151 \mathrm{bcd}$ & 127 e & $91 \mathrm{c}$ & $77 \mathrm{~b}$ & $3.24 \mathrm{bc}$ & $2.19 \mathrm{~b}$ \\
\hline Sadachikon & $150 \mathrm{bcd}$ & $138 \mathrm{de}$ & $143 \mathrm{~b}$ & 135 a & $4.74 \mathrm{a}$ & 4.44 \\
\hline Mutha & $155 \mathrm{bc}$ & 127 e & $93 \mathrm{c}$ & $70 \mathrm{~b}$ & $3.59 \mathrm{~b}$ & $2.10 \mathrm{~b}$ \\
\hline Lalchikon & $179 \mathrm{ab}$ & $136 \mathrm{de}$ & $78 \mathrm{c}$ & $74 \mathrm{~b}$ & $3.04 \mathrm{bc}$ & $2.18 \mathrm{~b}$ \\
\hline Lothor & $189 a$ & $172 \mathrm{ab}$ & $77 \mathrm{c}$ & $64 \mathrm{~b}$ & $2.63 \mathrm{c}$ & $2.11 \mathrm{~b}$ \\
\hline Sadapajam & $155 \mathrm{bcd}$ & $101 \mathrm{f}$ & $172 \mathrm{a}$ & $150 \mathrm{a}$ & $4.66 \mathrm{a}$ & 3.27 \\
\hline Average & $164 \mathrm{a}$ & $137 \mathrm{~b}$ & $104 \mathrm{a}$ & $91 \mathrm{~b}$ & $3.67 \mathrm{a}$ & 2.81 \\
\hline Variety (V) & \multicolumn{2}{|c|}{ NS } & \multicolumn{2}{|c|}{ * } & \multicolumn{2}{|c|}{. } \\
\hline Nitrogen $(\mathrm{N})$ & \multirow{2}{*}{\multicolumn{2}{|c|}{$\begin{array}{l}* * * \\
* * * \\
* * *\end{array}$}} & \multirow{2}{*}{\multicolumn{2}{|c|}{$*$}} & \multirow{2}{*}{\multicolumn{2}{|c|}{$m$}} \\
\hline$V \times N$ & & & & & & \\
\hline CV (\%) & \multicolumn{2}{|c|}{12.5} & \multicolumn{2}{|c|}{16.3} & \multicolumn{2}{|c|}{12.8} \\
\hline
\end{tabular}


Yield and Nitrogen Use Efficiency of Locally Improved Rice Varieties in Rice Based

Figures with same letters did not differ significantly. " and ${ }^{* * *}$ significant at 5 and $1 \%$ level. NS $=$ not significant.

Thus, this variety produced $42 \%$ more grain yield with addition of $\mathrm{N}$ compared to control. The cultivated local varieties, Razashail, Kutiagoni and Mutha produced more than $3.5 \mathrm{t} \mathrm{ha}^{-1}$ grains with addition of $\mathrm{N}$. On the other hand, all the cultivated varieties except Kutiagoni and Sadapajam produced less than $2.0 \mathrm{t} \mathrm{ha}^{-1}$ in control plots (Table 2). Razashail variety gave $28 \%$ higher yield with addition of $\mathrm{N}$ than control. Moreover, more than $1.0 \mathrm{t} \mathrm{ha}^{-1}$ yield advantages was obtained from local variety Lalpayka, Mutha and Sadapajam with addition of $\mathrm{N}$ compared to control. At Bakergonj, about $0.39 \mathrm{t} \mathrm{ha}^{-1}$ yield advantages was recorded from $\mathrm{N}$ plots which was $16 \%$ higher than FP plots in Sadamota variety (Table 3). At Batagi, in N-applied plot, cultivated Sadamota produced $3.43 \mathrm{t} \mathrm{ha}^{-1}$ which was $30 \%$ higher than FP plots (Table 4). The improved yield contributing attributes, such as panicle $\mathrm{m}^{-2}$ and grains panicle ${ }^{-1}$ might be responsible for improved yield of rice (Tables 2 to 4). Fageria and Santos (2014) reported that the low land rice genotypes gave significantly higher grain and yield, more panicles per unit areas and better root growth with the addition $\mathrm{N}$.

Table 3. Effect of urea deep placement on yield components of aman rice, Bakergonj, Barisal.

\begin{tabular}{|c|c|c|c|c|c|c|}
\hline \multirow{2}{*}{ Varieties } & \multicolumn{2}{|c|}{ Panicles $\mathrm{m}^{-2}$} & \multicolumn{2}{|c|}{ Grains panicle ${ }^{-1}$} & \multicolumn{2}{|c|}{ Grain yield $\left(\mathrm{t} \mathrm{ha}^{-1}\right)$} \\
\hline & N-applied & Control & N-applied & Control & N-applied & Control \\
\hline Sadamota & $142 \mathrm{~b}$ & $126 \mathrm{c}$ & $71 \mathrm{~b}$ & $61 \mathrm{~b}$ & 2.80 & 2.41 \\
\hline Moulata & $142 \mathrm{~b}$ & $130 \mathrm{c}$ & $86 \mathrm{a}$ & $78 \mathrm{a}$ & 2.92 & 2.34 \\
\hline Lalmota & 158 a & $138 \mathrm{bc}$ & $72 \mathrm{~b}$ & $64 \mathrm{~b}$ & 3.35 & 2.45 \\
\hline Average & $147 \mathrm{a}$ & $131 \mathrm{~b}$ & $76 \mathrm{a}$ & $68 \mathrm{~b}$ & $3.02 \mathrm{a}$ & $2.40 \mathrm{~b}$ \\
\hline Variety (V) & \multicolumn{2}{|c|}{ NS } & \multicolumn{2}{|l|}{ 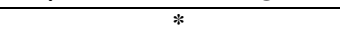 } & \multicolumn{2}{|c|}{ NS } \\
\hline Nitrogen $(\mathrm{N})$ & \multicolumn{2}{|c|}{$* *$} & \multicolumn{2}{|c|}{$* *$} & \multicolumn{2}{|c|}{$* *$} \\
\hline $\mathrm{V} \times \mathrm{N}$ & \multicolumn{2}{|c|}{$*$} & \multicolumn{2}{|c|}{$*$} & \multicolumn{2}{|c|}{$*$} \\
\hline CV (\%) & \multicolumn{2}{|c|}{12.5} & \multicolumn{2}{|c|}{12.5} & \multicolumn{2}{|c|}{12.8} \\
\hline
\end{tabular}

Figures with same letters did not differ significantly. ${ }^{*}$ and ${ }^{* *}$ significant at 5 and $1 \%$ level. NS $=$ not significant.

Table 4. Effect of urea deep placement on yield components of aman rice, Batagi, Borguna.

\begin{tabular}{|c|c|c|c|c|c|c|}
\hline \multirow{2}{*}{ Varieties } & \multicolumn{2}{|c|}{ Panicles $\mathrm{m}^{-2}$} & \multicolumn{2}{|c|}{ Grains panicle ${ }^{-1}$} & \multicolumn{2}{|c|}{ Grain yield $\left(\mathrm{t} \mathrm{ha}{ }^{-1}\right)$} \\
\hline & N-applied & Control & N-applied & Control & N-applied & Control \\
\hline Lalmota & $177 \mathrm{ab}$ & $146 \mathrm{~b}$ & $74 \mathrm{a}$ & $65 \mathrm{~b}$ & $3.76 \mathrm{a}$ & $2.61 \mathrm{~b}$ \\
\hline Moulata & $185 \mathrm{a}$ & $172 \mathrm{a}$ & $72 \mathrm{a}$ & $63 \mathrm{~b}$ & $3.05 \mathrm{a}$ & $2.54 \mathrm{~b}$ \\
\hline Sadamota & $172 \mathrm{~b}$ & $144 \mathrm{~b}$ & $68 \mathrm{~b}$ & $64 \mathrm{~b}$ & $3.43 \mathrm{a}$ & $2.40 \mathrm{~b}$ \\
\hline Average & $178 \mathrm{a}$ & $154 \mathrm{~b}$ & $71 \mathrm{a}$ & $64 \mathrm{~b}$ & $3.41 \mathrm{a}$ & $2.52 \mathrm{~b}$ \\
\hline Variety (V) & \multicolumn{2}{|l|}{180} & \multicolumn{2}{|c|}{ NS } & \multicolumn{2}{|c|}{ NS } \\
\hline Nitrogen $(\mathrm{N})$ & \multicolumn{2}{|c|}{$* *$} & \multicolumn{2}{|c|}{$\begin{array}{l}* * \\
* *\end{array}$} & \multicolumn{2}{|c|}{ *** } \\
\hline $\mathrm{V} \times \mathrm{N}$ & \multicolumn{2}{|c|}{$*$} & \multicolumn{2}{|c|}{$* *$} & \multicolumn{2}{|c|}{$*$} \\
\hline $\mathrm{CV}(\%)$ & \multicolumn{2}{|c|}{11.4} & \multicolumn{2}{|c|}{11.0} & \multicolumn{2}{|c|}{15.1} \\
\hline
\end{tabular}

Figures with same letters did not differ significantly. ${ }^{*}$ and ${ }^{* * *}$ significant at 5 and $1 \%$ level. NS $=$ not significant.

Total nitrogen uptake

At Gournadi, the highest total $\mathrm{N}$ uptake was recorded from Sdapajam when $\mathrm{N}$ applied (Table 5). Local varieties Razashail, Kutiagoni, Lalpayka and Lalchikon uptake 
Mamun et al.

similar total $\mathrm{N}$. The lowest $\mathrm{N}$ uptake at $\mathrm{N}$ applied plot was obtained in Lothor. At Bakergonj, the highest total $\mathrm{N}$ uptake was recorded from Lalmota in both $\mathrm{N}$ and control. Sadamota uptake total $\mathrm{N}$ by 57.25 and $43.25 \mathrm{~kg} \mathrm{~N}$ ha ${ }^{-1}$ with $\mathrm{N}$ and control, respectively (Table 6). At Batagi, the highest total $\mathrm{N}$ uptake was recorded from Sadamota followed by Lalmota when urea super granule was applied. In control plots, the highest total $\mathrm{N}$ was recorded from the variety Moulata (Table 7). Deep placement of urea $(\mathrm{N})$ exerted significant influence on total $\mathrm{N}$ uptake (Tables 5 to 7). Significantly higher amount of $\mathrm{N}$ was taken up by grain and straw due to application of urea in all varieties. At Gournadi, $32.18 \mathrm{~kg}^{-1}$ more total $\mathrm{N}$ was taken up by addition of $\mathrm{N}$ which was $58 \%$ higher than that of control plot in Razashail variety (Table 5).

Table 5. Effect of urea deep placement on internal efficiency of aman rice, Gournadi, Barisal

\begin{tabular}{|c|c|c|c|c|}
\hline \multirow{2}{*}{ Varieties } & \multicolumn{2}{|c|}{ Total $\mathrm{N}$ uptake $\left(\mathrm{kg} \mathrm{N} \mathrm{ha}{ }^{-1}\right)$} & \multicolumn{2}{|c|}{ Internal efficiency $\left(\mathrm{kg}\right.$ grain $\left.\mathrm{kg}^{-1} \mathrm{~N}\right)$} \\
\hline & N-applied & Control & N-applied & Control \\
\hline Razashail & $87.45 \mathrm{~b}$ & $55.27 \mathrm{~b}$ & $41.54 \mathrm{ab}$ & $50.78 \mathrm{ab}$ \\
\hline Kutiagoni & $79.31 \mathrm{~b}$ & $63.44 \mathrm{~b}$ & $48.73 \mathrm{a}$ & $52.7 \mathrm{ab}$ \\
\hline Lalpayka & $77.54 \mathrm{~b}$ & $46.02 \mathrm{bc}$ & $41.8 \mathrm{ab}$ & $47.14 \mathrm{c}$ \\
\hline Sadachikon & $103.95 \mathrm{a}$ & $77.89 \mathrm{a}$ & $45.62 \mathrm{a}$ & $57.07 \mathrm{a}$ \\
\hline Mutha & $103.1 \mathrm{a}$ & $52.16 \mathrm{~b}$ & $35.05 \mathrm{c}$ & $40.24 \mathrm{~d}$ \\
\hline Lalchikon & $86.58 \mathrm{~b}$ & $50.77 \mathrm{bc}$ & $35.2 \mathrm{c}$ & $43.07 \mathrm{~cd}$ \\
\hline Lothor & $58.07 \mathrm{c}$ & $41.96 \mathrm{bc}$ & $45.41 \mathrm{a}$ & $50.31 \mathrm{bc}$ \\
\hline Sadapajam & $106.51 \mathrm{a}$ & $58.03 \mathrm{~b}$ & 43.78 a & $56.45 \mathrm{ab}$ \\
\hline Average & $87.81 \mathrm{a}$ & $55.69 \mathrm{~b}$ & $42.14 \mathrm{~b}$ & $49.72 \mathrm{a}$ \\
\hline Variety $(\mathrm{V})$ & \multicolumn{2}{|r|}{$4.0 \% 0$} & \\
\hline Nitrogen $(\mathrm{N})$ & \multicolumn{2}{|c|}{$* *$} & \multicolumn{2}{|c|}{$* *$} \\
\hline $\mathrm{V} \times \mathrm{N}$ & \multicolumn{2}{|c|}{ 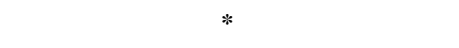 } & \multicolumn{2}{|c|}{$* *$} \\
\hline $\mathrm{CV}(\%)$ & \multicolumn{2}{|c|}{15.1} & \multicolumn{2}{|c|}{8.2} \\
\hline
\end{tabular}

Figures with same letters did not differ significantly. ${ }^{*}$ and ${ }^{* *}$ significant at 5 and $1 \%$ level. NS $=$ not significant.

Table 6. Effect of urea deep placement on internal efficiency of aman rice, Bakergonj, Barisal

\begin{tabular}{|c|c|c|c|c|}
\hline \multirow[t]{2}{*}{ Varieties } & \multicolumn{2}{|c|}{$\begin{aligned} \text { Total } & \mathrm{N} \text { uptake } \\
(\mathrm{kg} & \mathrm{N} \mathrm{ha}\end{aligned}$} & \multicolumn{2}{|c|}{$\begin{array}{l}\text { Internal efficiency } \\
\left(\mathrm{kg} \text { grain } \mathrm{kg}^{-1} \mathrm{~N}\right)\end{array}$} \\
\hline & N-applied & Control & N-applied & Control \\
\hline Sadamota & $57.25 \mathrm{~b}$ & $43.25 \mathrm{a}$ & 49.70 & 56.11 \\
\hline Moulata & $58.41 \mathrm{~b}$ & $38.41 \mathrm{~b}$ & 51.09 & 61.71 \\
\hline Lalmota & $69.07 \mathrm{a}$ & $47.08 \mathrm{a}$ & 49.05 & 51.82 \\
\hline Average & $61.58 \mathrm{a}$ & $42.91 \mathrm{~b}$ & $49.95 \mathrm{~b}$ & 56.55 \\
\hline Variety (V) & \multicolumn{2}{|c|}{ * } & \multicolumn{2}{|c|}{ NS } \\
\hline Nitrogen (N) & \multicolumn{2}{|c|}{$* *$} & \multicolumn{2}{|c|}{$* *$} \\
\hline $\mathrm{V} \times \mathrm{N}$ & \multicolumn{2}{|c|}{$* *$} & \multicolumn{2}{|c|}{$*$} \\
\hline CV (\%) & \multicolumn{2}{|c|}{18.2} & \multicolumn{2}{|c|}{12} \\
\hline
\end{tabular}

Figures with same letters did not differ significantly. ${ }^{*}$ and ${ }^{* *}$ significant at 5 and $1 \%$ level. NS $=$ not significant. 
Yield and Nitrogen Use Efficiency of Locally Improved Rice Varieties in Rice Based

This means that the $\mathrm{N}$ applied at late growth stage of rice was absorbed by the grain and straw. Fageria and Baligar (1999) also reported that $\mathrm{N}$ applied late during the reproductive growth stage absorbed by the crop and improve grain yield.

Table 7. Effect of urea deep placement on internal efficiency of aman rice, Batagi, Borguna

\begin{tabular}{|c|c|c|c|c|}
\hline \multirow[t]{2}{*}{ Varieties } & \multicolumn{2}{|c|}{$\begin{array}{r}\text { Total } \mathrm{N} \text { uptake } \\
\left(\mathrm{kg} N \mathrm{ha}^{-1}\right)\end{array}$} & \multicolumn{2}{|c|}{$\begin{array}{l}\text { Internal efficiency } \\
\left(\mathrm{kg} \text { grain } \mathrm{kg}^{-1} \mathrm{~N}\right)\end{array}$} \\
\hline & N-applied & Control & N-applied & Control \\
\hline Lalmota & 62.24 & 36.21 & 60.35 & 72.51 \\
\hline Moulata & 53.39 & 39.35 & 57.51 & 66.26 \\
\hline Sadamota & 62.75 & 37.43 & 54.87 & 64.11 \\
\hline Average & $59.46 \mathrm{a}$ & $37.66 \mathrm{~b}$ & $57.58 \mathrm{~b}$ & $67.63 \mathrm{a}$ \\
\hline Variety (V) & \multicolumn{2}{|c|}{ NS } & \multicolumn{2}{|c|}{ NS } \\
\hline Nitrogen $(\mathrm{N})$ & \multicolumn{2}{|c|}{$*$} & \multicolumn{2}{|c|}{$* *$} \\
\hline $\mathrm{V} \times \mathrm{N}$ & \multicolumn{2}{|c|}{ * } & \multicolumn{2}{|c|}{$*$} \\
\hline CV (\%) & \multicolumn{2}{|c|}{16.1} & \multicolumn{2}{|c|}{13.8} \\
\hline
\end{tabular}

Figures with same letters did not differ significantly. ${ }^{*}$ and ${ }^{* *}$ significant at 5 and $1 \%$ level. NS $=$ not significant.

Nitrogen use efficiency and partial factor productivity

The internal efficiency (IE) was higher in control than $\mathrm{N}$ applied plot in all varieties. At Gournadi, Kutiagoni gave the highest internal efficiency in $\mathrm{N}$ applied plot (Table 5). At Bakergonj, Moulata gave the IE in $\mathrm{N}$ applied plots (Table 6). At Batagi, among the cultivated varieties Lalmota gave the highest IE in $\mathrm{N}$ plots (Table 7). At Gournadi, the highest Agronomic efficiency (AE) was recorded from Mutha followed by Sadapajam (Table 8). At Bakergonj, the highest $\mathrm{AE}$ of $\mathrm{N}$ was recorded from Lalmota (Table 9). At Batagi, statistically the highest $\mathrm{AE}$ of urea was recorded from Sadamota followed by Lalmota. The lowest $\mathrm{AE}$ was recorded from Moulata were (Table 10). At Gournadi, the highest partial factor productivity (PFP) was recorded from Sadapajam in Gournadi (Table 8). Rest of the varieties gave less than $200 \mathrm{~kg}_{\text {grain }} \mathrm{kg}^{-1} \mathrm{~N}$ as PFP. At Bakergonj, the highest PFP of urea was recorded from Lalmota (Table 9). At Batagi, the highest PFP of urea was recorded from Sadamota. The PFP of rest two varieties like Lalmota and Moulata were 198.76 and $172.33 \mathrm{~kg}_{\text {grain }} \mathrm{kg}^{-1} \mathrm{~N}$ (Table 10). At Gournadi, recovery efficiency (RE) of $\mathrm{N}$ application was significantly $(\mathrm{P}<0.05)$ influenced by cultivated varieties in all locations (Table 8). The lowest RE was obtained from Kutiagoni and Lothor. At Bakergonj, the highest RE of urea was recorded from Lalmota followed by Moulata (Table 9). The lowest RE was obtained from Sadamota (9.24 kg grain $\mathrm{kg}^{-1} \mathrm{~N}$ uptake). At Batagi, significantly the highest $\mathrm{RE}$ was recorded from Sadamota which was statistically significantly with that of Lalmota (Table 10). Cultivated varieties influenced $(\mathrm{P}<0.05)$ physiological efficiency $(\mathrm{PE})$ of $\mathrm{N}$ (Table 8). The highest PE of $\mathrm{N}$ was recorded from Lothor followed by Lalpayka in Gournadi. These two varieties gave $\mathrm{PE}$ by more than $30 \mathrm{~kg}$ grain $\mathrm{kg}^{-1} \mathrm{~N}$ uptake. At Bakergonj, the highest PE of urea was recorded from Lalmota (Table 9). At Batagi, the highest PE of urea was recorded from Lalmota followed by Sadamota (Table 10). Application of $\mathrm{N}$ in the root zone areas increased grain yield over no fertilization in rice is already well-well documented (Alam et al., 2013). Deep placement of $\mathrm{N}$ remain in soil for longer time which ensure continuous $\mathrm{N}$ supply to the crop throughout the life cycle and increases grain yield and use efficiency. Fageria and Baligar (2001) reported that physiological efficiency was $146 \mathrm{~kg}$ biological yield per unit of $\mathrm{N}$ accumulated in 
Mamun et al.

flooded rice cultivar Metica 1. Singh et al. (1998) reported an N recovery efficiency of $37 \%$ in 20 low land rice genotypes. Furthermore, nitrogen recovery efficiency for lowland rice is less than 50\% (Fageria and Baligar, 2005). A flooded rice variety, Metica 1, from South America showed an average UE of $58 \mathrm{~kg} \mathrm{~kg}^{-1}$ across $\mathrm{N}$ rates (Fageria and Baligar, 2001). Yoshida (1981) also reported that the efficiency of utilization for grain production in the tropics is about $50 \mathrm{~kg}$ grain per $\mathrm{kg} \mathrm{N}$ absorbed and this efficiency appears to be almost constant regardless of the rice yields achieved. Agronomic efficiency in low land rice in the tropics is reported to be in the range of 15 to $25 \mathrm{~kg}$ grain produced per $\mathrm{kg}$ of applied $\mathrm{N}$ (Yoshida, 1981). Physiological $\mathrm{N}$ use efficiency varied from 11.41 to $32.64,32.50$ to 42.37 and 35.80 to $41.67 \mathrm{~kg}$ $\mathrm{kg}^{-1}$ at Gounadi, Bakergonj and Batagi, respectively. Fageria and Baligar (2001) reported that physiological efficiency was $146 \mathrm{~kg}$ biological yield per unit of $\mathrm{N}$ accumulated in flooded rice cultivar Metica 1.

Table 8. Variety wise $\mathrm{N}$ use efficiencies of urea super granule application, Gournadi, Barisal

\begin{tabular}{|c|c|c|c|c|}
\hline Varieties & $\begin{array}{c}\text { Agronomic } \\
\text { efficiency } \\
\left(\mathrm{kg} \text { grain } \mathrm{kg}^{-1} \mathrm{~N}\right)\end{array}$ & $\begin{array}{c}\text { Partial factor } \\
\text { productivity } \\
\left(\mathrm{kg} \text { grain } \mathrm{kg}^{-1} \mathrm{~N}\right)\end{array}$ & $\begin{array}{l}\text { Recovery } \\
\text { efficiency } \\
(\%)\end{array}$ & $\begin{array}{c}\text { Physiological } \\
\text { efficiency } \\
\left(\mathrm{kg} \text { grain } \mathrm{kg}^{-1} \mathrm{~N}\right)\end{array}$ \\
\hline Razasail & $40.55 \mathrm{c}$ & $188.81 \mathrm{~b}$ & $16.63 \mathrm{~d}$ & $20.8 c$ \\
\hline Kutiagoni & $26.18 \mathrm{~d}$ & $199.60 \mathrm{~b}$ & $8.4 e$ & $28.36 \mathrm{ab}$ \\
\hline Lalpayka & $52.39 \mathrm{c}$ & $169.31 \mathrm{c}$ & $15.84 \mathrm{~d}$ & 30.98 a \\
\hline Sadacikon & $12.5 e$ & $199.18 \mathrm{~b}$ & $10.94 e$ & $11.41 \mathrm{~d}$ \\
\hline Mutha & $79.82 \mathrm{a}$ & $188.47 b$ & $27.58 \mathrm{a}$ & $29.63 \mathrm{a}$ \\
\hline Lalcikon & $46.3 \mathrm{c}$ & $164.01 \mathrm{c}$ & $19.27 \mathrm{c}$ & $24.03 \mathrm{c}$ \\
\hline Lothor & $25.85 \mathrm{~d}$ & $129.62 \mathrm{~d}$ & $7.92 e$ & $32.64 \mathrm{a}$ \\
\hline Sadapajam & $68.22 \mathrm{~b}$ & $229.29 \mathrm{a}$ & $23.84 \mathrm{~b}$ & $28.62 \mathrm{ab}$ \\
\hline Average & 43.98 & 183.54 & 16.30 & 25.81 \\
\hline F-Test & $* *$ & $* *$ & $* *$ & * \\
\hline CV (\%) & 23.7 & 25.5 & 26.7 & 27.6 \\
\hline
\end{tabular}

Figures with same letters did not differ significantly. * and ${ }^{* *}$ significant at 5 and $1 \%$ level.

Table 9. Variety wise $\mathrm{N}$ use efficiencies of urea super granule application, Bakergonj, Barisal

\begin{tabular}{lcccc}
\hline Varieties & $\begin{array}{c}\text { Agronomic } \\
\text { efficiency } \\
\text { grain kg-1 }\end{array}$ & $\begin{array}{c}\text { Partial factor } \\
\text { productivity } \\
(\mathrm{kg} \text { grain kg-1 }\end{array}$ & $\begin{array}{c}\text { Recovery } \\
\text { efficiency } \\
(\%)\end{array}$ & $\begin{array}{c}\text { Physiological } \\
\text { efficiency } \\
\left(\mathrm{kg}_{\text {grain }} \mathrm{kg}^{-1} \mathrm{~N}\right)\end{array}$ \\
\hline Sadamota & $25.94 \mathrm{c}$ & $185.40 \mathrm{~b}$ & $9.24 \mathrm{~b}$ & $33.99 \mathrm{~b}$ \\
Moulata & $39.38 \mathrm{~b}$ & $197.07 \mathrm{~b}$ & $14.11 \mathrm{a}$ & $32.50 \mathrm{~b}$ \\
Lalmota & $60.35 \mathrm{a}$ & $230.88 \mathrm{a}$ & $14.83 \mathrm{a}$ & $42.37 \mathrm{a}$ \\
\hline Average & 41.89 & 204.45 & 12.73 & 36.29 \\
\hline F-Test & $* *$ & $*$ & $* *$ & $*$ \\
CV $(\%)$ & 27.5 & 30.3 & 29.3 & 32.2 \\
\hline
\end{tabular}

Figures with same letters did not differ significantly. * and ** significant at 5 and $1 \%$ level. 
Yield and Nitrogen Use Efficiency of Locally Improved Rice Varieties in Rice Based

Table 10. Variety wise $\mathrm{N}$ use efficiencies of urea super granule application, Batagi, Borguna

\begin{tabular}{lcccc}
\hline Varieties & $\begin{array}{c}\text { Agronomic } \\
\text { efficiency } \\
\left.\text { grain kg } \mathrm{kg}^{-1} \mathrm{~N}\right)\end{array}$ & $\begin{array}{c}\text { Partial factor } \\
\text { productivity } \\
\left(\mathrm{kg} \mathrm{grain} \mathrm{kg}^{-1} \mathrm{~N}\right)\end{array}$ & $\begin{array}{c}\text { Recovery } \\
\text { gfficiency } \\
(\%)\end{array}$ & $\begin{array}{c}\text { Physiological } \\
\text { efficiency } \\
\text { grain kg }\end{array}$ \\
\hline Lalmota & $56.25 \mathrm{~b}$ & $198.76 \mathrm{~b}$ & $13.40 \mathrm{~b}$ & $41.67 \mathrm{a}$ \\
Moulata & $27.73 \mathrm{c}$ & $172.33 \mathrm{c}$ & $7.97 \mathrm{c}$ & $35.80 \mathrm{~b}$ \\
Sadamota & $66.01 \mathrm{a}$ & $221.47 \mathrm{a}$ & $16.81 \mathrm{a}$ & $41.18 \mathrm{a}$ \\
\hline Average & 50.00 & 197.52 & 12.73 & 39.55 \\
\hline F-Test & $*$ & 22.1 & 24.2 & $*$ \\
CV $(\%)$ & 20.1 & 24.3 \\
\hline
\end{tabular}

Figures with same letters did not differ significantly. * and ** significant at 5 and $1 \%$ level.

Nitrogen harvest index and grain yield efficiency index

At Gournadi, the maximum $\mathrm{N}$ harvest index was obtained from Kutiagoni which was statistically identical with Lalpayka, Sadachikon and Sadapajam (Table 11). At Bakergonj, the $\mathrm{N}$ harvest index was obtained from Moulata followed by other two varieties (Table 12). On the other hand, the $\mathrm{N}$ harvest index was recorded from Lalmota amd Moulata at Batagi (Table 13). At Gournadi, the highest grain yield efficiency index was obtained from Sadachikon followed by Sadapajam (Table 11).

Table 11. Grain yield efficiency index of local aman rice, Gournadi, Barisal

\begin{tabular}{lccc}
\hline \multirow{2}{*}{ Varieties } & N harvest index & \multicolumn{2}{c}{ Grain yield efficiency index } \\
\cline { 3 - 4 } & & Value & Comments \\
\hline Razashail & $0.69 \mathrm{ab}$ & $1.05 \mathrm{c}$ & Efficient \\
Kutiagoni & $0.76 \mathrm{a}$ & $1.39 \mathrm{~b}$ & Efficient \\
Lalpayka & $0.73 \mathrm{a}$ & $0.78 \mathrm{~d}$ & Moderately efficient \\
Sadachikon & $0.71 \mathrm{a}$ & $1.69 \mathrm{a}$ & Efficient \\
Mutha & $0.68 \mathrm{bc}$ & $0.79 \mathrm{~d}$ & Moderately efficient \\
Lalchikon & $0.63 \mathrm{bc}$ & $0.69 \mathrm{~d}$ & Moderately efficient \\
Lothor & $0.68 \mathrm{bc}$ & $0.58 \mathrm{~d}$ & Moderately efficient \\
Sadapajam & $0.75 \mathrm{a}$ & $1.59 \mathrm{ab}$ & Efficient \\
\hline F-Test & $*$ & $*$ & \\
CV (\%) & 5.5 & 11.8 & \\
\hline
\end{tabular}

Figures with same letters did not differ significantly. " significant at $5 \%$ level.

Table 12. Grain yield efficiency index of local aman rice, Bakergonj, Barisal

\begin{tabular}{lccc}
\hline \multirow{2}{*}{ Varieties } & $\mathrm{N}$ harvest index & \multicolumn{2}{c}{ Grain yield efficiency index } \\
\cline { 3 - 4 } & & Value & Comments \\
\hline Sadamota & $0.62 \mathrm{c}$ & $0.95 \mathrm{~b}$ & Moderately efficient \\
Moulata & $0.65 \mathrm{a}$ & $0.95 \mathrm{~b}$ & Moderately efficient \\
Lalmota & $0.63 \mathrm{~b}$ & $1.13 \mathrm{a}$ & Efficient \\
\hline F-Test & $*$ & $* *$ & \\
CV $(\%)$ & 10.7 & 12.03 & \\
\hline
\end{tabular}

Figures with same letters did not differ significantly. * significant at $5 \%$ level. 
Mamun et al.

At Bakergonj and Batagi, the highest grain yield efficiency index was obtained from Lalmota (Table 12 and 13). Lalmota was efficient in both locations. Rattunde and Frey (1986) reported that the $\mathrm{N}$ harvest index was positively associated with grain yield of oats and response of grain yield. Similarly, Kairudin and Erey (1988) also reported that $\mathrm{N}$ harvest index of oats was positively correlated with grain yield and gross protein yield in low and high $\mathrm{N}$.

Table 13. Grain yield efficiency index of local aman rice, Batagi, Borguna

\begin{tabular}{lccc}
\hline \multirow{2}{*}{ Varieties } & N harvest index & \multicolumn{2}{c}{ Grain yield efficiency index } \\
\cline { 3 - 4 } & & Value & Comments \\
\hline Lalmota & $0.65 \mathrm{a}$ & $1.24 \mathrm{a}$ & Efficient \\
Moulata & $0.64 \mathrm{a}$ & $0.97 \mathrm{~b}$ & Moderately efficient \\
Sadamota & $0.62 \mathrm{~b}$ & $1.02 \mathrm{~b}$ & Efficient \\
F-Test & 7.1 & 17.2 & \\
CV (\%) & & & \\
\hline
\end{tabular}

Figures with same letters did not differ significantly. * significant at $5 \%$ level.

\section{Conclusion}

Results of this study showed that cultivated aman varieties produced 2.0 to $2.5 \mathrm{t} \mathrm{ha}^{-1}$ grain without application of $\mathrm{N}$ fertilizer. But, local variety Razashail, Kutiagoni, Sadachikon, Sadapajam, Lalmota and Sadamota varieties gave 3.0 to $3.5 \mathrm{t}$ ha $^{-1}$ grain in tidal prone areas with the deep placement of urea super granule (USG). Similarly, the highest internal, agronomic, recovery and physiological efficiency; nitrogen harvest and grain yield efficiency index was obtained from Kutiagoni, Lalpayka, Sadachikon, Sadapajam, Moulata and Lalmota. Thus, application of USG before panicle initiation stage is an effective option for urea application in tidal prone areas.

\section{References}

Alam, M. M., M. R. Karim and J. K. Ladha. 2013. Integrating best management practice for rice with farmers' crop management techniques: A potential option for minimizing rice yield gap. Field Crops Res. 144: 62-68.

Fageria, N. K. and A. B. Santos. 2014. Lowland rice genotypes evaluation for nitrogen use efficiency. J. Plant Nutr. 37(9): 1410-1423.

Dobermann, A. and T. Fairhast. 2000. Rice: Nutrient disorders and nutrient management. Oxford Graphic Printers Pte Ltd. Pp. 1-191.

Elahi, N. E., M. A. H. Khan, M. A. I. Khan, M. R. Islam, M. A. Salam, M. A. Hossain and A. U. Ahmed. 2001. Research report of the tidal non-saline sub-ecosystem for the year 2001. IFAD planning meeting held on 13 January, 2001, Dhaka, Bangladesh.

Fageria, N. K. 2009. The Use of Nutrients in Crop Plants. Boca Raton, FL: CRC Press.

Fageria, N. K. and Baligar, V. C. 1999. Yield and yield components of lowland rice as influenced by timing of nitrogen fertilization. J. Plant Nutr. 22: 23-32.

Fageria, N. K. (2007). Yield physiology of rice. J. Plant Nutr. 30: 843-879.

Fageria, N. K. and V. C. Baligar. 2001. Lowland rice response to nitrogen fertilization. Commun. Soil Sci. Plant Anal. 32: 1405-1429. 
Yield and Nitrogen Use Efficiency of Locally Improved Rice Varieties in Rice Based

Fageria, N. K. and V. C. Baligar. 2005. Enhancing nitrogen use efficiency in crop plants. Adv. Agron. 88: 97-185.

Gomez, K. A. and A. A. Gomez. 1984. Statistical procedure for agricultural research $\left(2^{\text {nd }}\right.$ edn.). John Willey and Sons, Singapore. Pp. 28-192.

Hassan, M. S., A. Khair, M. M. Haque, A. K. Azad and A. Hamid. 2009. Genotypic variation in traditional rice varieties for chlorophyll content, SPAD value and nitrogen use efficiency. Bangladesh J. Agril. Res. 34(3): 505-515.

Hossain, M. A., B. C. Roy, S. S. Haque, M. A. I. Khan and A. W. Julfiquar. 2002. Potentiality of hybrid rice in the south central region of Bangladesh. Hybrid rice in Bangladesh, Progress and Future Strategies. Bangladesh Rice Research Institute, Pp: 51-52.

IFDC. 2013. Fertilizer deep placement. IFDC solutions. Int. Fertilizer Development Center, Muscle Shoals, AL. http://issuu.com/ifdcinfo/ docs/fdp_8pg_final_web.

Kairudin, N. M. D. and K. J. Frey. 1988. Soil N availability and nitrogen harvest index of oats. J. Iowa Acad. Sci. 95: 73-78.

Mnzava, M. M. W. 2002. Nitrogen absorption rate at different growth stages in relation to grain production of lowland rice. Ph.D. Thesis, Los Banos, Philippines: University of Philippines.

Rajput, M. K. K., A. H. Ansari, S. Mehdi and A. M. Hussain. 1988. Effect of N and P fertilizers alone and in combination with $\mathrm{OM}$ on the growth and yield of Toria. Sarhad J. Agri. Res. 4: 3-6.

Rattunde, H. F. and K. J. Frey. 1986. Nitrogen harvest index in oats: its repeatability and association with adaptation. Crop Sci. 26: 606-610.

Russell, D. 2010. MSTAT-C. Design, Management and Statistical Tool. Plant and Soil Science. Michigan State University. 384C East Lansing, MI 48824.

Rochette, P., D. A. Angers, M. H. Chantigny, M. O. Gasser, J. D. Mac-Donald, D. E. Pelster and N. Bertrand. 2013. Ammonia volatilization and nitrogen retention: How deep to incorporate urea? J. Environ. Qual. 42: 1635-1642.

Singh, U., J. K. Ladha, E. G. Castillo, G. Punjalan, A. Tirol-Padre and M. Duquesa. 1998. Genotypic variation in nitrogen use efficiency in medium and long duration rice. Field Crop Res. 58: 35-53.

Yoshida, S. 1981. Fundamentals of rice crop science. IRRI, Los Banos, Philippines. P. 269.

Yoshida, S. and V. Coronel. 1976. Nitrogen nutrition, leaf resistance, and leaf photosynthetic rate of the rice plant. Soil. Sci. Plant Nutr. 22: 207-211. 